\title{
Effect of Pomphorhynchus laevis (Acanthocephala) on putative neuromodulators in the intestine of naturally infected Salmo trutta
}

\author{
Bahram Sayyaf Dezfuli ${ }^{1, *}$, Flavio Pironi ${ }^{1}{ }^{,}$Luisa Giari ${ }^{1}$, Cinzia Domeneghini ${ }^{2}$, \\ Giampaolo Bosi ${ }^{2}$ \\ ${ }^{1}$ Department of Biology, University of Ferrara, Via Borsari 46, 44100 Ferrara, Italy \\ ${ }^{2}$ Institute of Domestic Animals Anatomy, Histology and Embryology, Faculty of Veterinary Medicine, Via Celoria 10, \\ 20133 Milan, Italy
}

\begin{abstract}
Immunohistochemical and pathological studies were carried out on the digestive tract of parasitized and uninfected specimens of Salmo trutta (L.). A total of 124 brown trout were collected on several occasions from 3 tributaries of the Brenta River, northern Italy. Twenty-eight individuals of $S$. trutta $(22.6 \%)$ were parasitized with Pomphorhynchus laevis (Müller, 1776). The occurrence of $P$. laevis in the trout gut significantly increased the number of endocrine cells immunoreactive to calcitonin gene-related peptide (CGRP), $\beta$-endorphin, met-enkephalin, neuropeptide Y (NPY) and Substance P (SP) antisera. Moreover, bombesin-, cholecistokinin-8- (CCK-8), leu-enkephalin- and serotonin- (5-HT)-like immunoreactive cells were less numerous in the intestine of the parasitized brown trout. A strong positive immunoreactivity was observed in nerve fibres and neurones of the myenteric plexus of the parasitized fish; the antisera involved in this positive reactivity were bombesin, metenkephalin, SP and vasoactive intestinal peptide (VIP). More neurones immunoreactive to antiCGRP and anti-5-HT sera were noted in the myenteric plexus and in the inner layer of the tunica muscularis of the infected fish. Most of the above-mentioned neuromodulators are known to control gut motility, digestive/absorptive processes, as well as the immune response. The changes induced by parasites in the neuroendocrine system of the brown trout are discussed.
\end{abstract}

KEY WORDS: Acanthocephalan infection - Immunohistochemical · Neuromodulators · Digestive tract $\cdot$ Salmo trutta

Resale or republication not permitted without written consent of the publisher

\section{INTRODUCTION}

Some reports on the effects of endoparasitic helminths on the digestive tract and associated organs of fishes appeared in McDonough \& Gleason (1981), Dezfuli (1991), Dezfuli et al. (2000), and Taraschewski (2000). Generally, the extent of damage caused by helminths is related to the intensity of infection and depth of parasite penetration within the host tissues.

*E-mail: dzb@dns.unife.it
Most intestinal nematodes, cestodes and trematodes do not cause severe damage to the host alimentary canal, mainly due to the shallow entry of these worms into the tissues. With reference to the Acanthocephala, their pathogenecity is due to 2 factors: density of parasite burden and depth of penetration into the vertebrate tissues (Bullock 1963). Concerning the second factor, members of some acanthocephalan genera, e.g. Acanthocephalus (Taraschewski 1989), Pomphorhynchus (Dezfuli 1991) and Southwellina (Dezfuli et al. 1998) penetrate deeply into the tissue and induce extensive damage to the digestive tract. 
Pomphorhynchus laevis is a common parasite of several species of freshwater fishes (Bykhovskaya-Pavlovskaya 1964); indeed, in the study area, among the acanthocephalan parasites of Salmo trutta, P. laevis was the most frequent (Dezfuli et al. 2001). Histopathological effects of this worm on fishes, such as Leuciscus cephalus were reported by Mehlhorn et al. (1988) and Dezfuli (1991).

Host structural modifications due to enteric helminths are the counterpart of biochemical and physiological changes (Castro 1992, Fairweather 1997). In mammals, the nervous, endocrine, and immune systems cooperate to elicit host responses to the intestinal parasites (Fairweather 1997), and many peptides and amines are involved in the communication among cells of these systems (Blalock 1989, O'Dorisio \& Panerai 1990). With reference to mammals, the topic that enteric helminths can affect the distribution of neuromodulators of the host gut and induce host responses has drawn the attention of a number of workers in the recent past (McKay et al. 1991, Varilek et al. 1991, Foster \& Lee 1996, Fairweather 1997). However, to date, there have been only very limited observations on the occurrence and distribution of neuromodulators in the intestine of infected fishes (Maule et al. 1989, Dezfuli et al. 2000). Recently, with immunohistochemical methods, the presence and frequency of nervous, endocrine and immune structures positive to 6 neuromodulators, namely Substance P (SP), calcitonin generelated peptide (CGRP), met-enkephalin, neuropeptide $\mathrm{Y}$ (NPY), vasoactive intestinal peptide (VIP), and serotonin (5-HT) antisera were investigated in the brown trout parasitized with cestodes (Dezfuli et al. 2000).

The present study was undertaken to ascertain for the first time the distribution of 11 putative neuromodulators in Salmo trutta infected with the acanthocephalan Pomphorhynchus laevis. The data presented will be discussed in relation to the regulatory role played by neuromodulators in gut physiological processes.

\section{MATERIALS AND METHODS}

From January 2000 to February 2001 a total of 124 specimens of Salmo trutta (ranging from 22 to $40 \mathrm{~cm}$ in total length) were collected on several occasions from 3 tributaries of the Brenta River, northern Italy. Fish were sampled by electrofishing and anesthetized with $\beta, \beta, \beta-$ trichloro-tert-butyl alcohol and then dissected. Pieces of the middle and distal regions of the medium intestine tissue (mostly up to $12 \mathrm{~mm}$ in length) of 28 specimens of $S$. trutta with attached parasites were fixed in Bouin's fluid $\left(7 \mathrm{~h}\right.$ at $\left.4^{\circ} \mathrm{C}\right)$. For the present survey, only trout infected with Pomphorhynchus laevis were chosen. After dehydration, samples were embedded in paraffin with a melt- ing point of $58^{\circ} \mathrm{C}$. The samples were sectioned at about $7 \mu \mathrm{m}$, and stained with the haematoxylin-eosin, AzanMallory, and periodic acid-Schiff (PAS) methods. Immunohistochemical tests were applied to sections of intestinal tissue. Dewaxed and hydrated sections were treated with $0.6 \% \mathrm{H}_{2} \mathrm{O}_{2}$ in methanol for $15 \mathrm{~min}$, and with normal rabbit serum (1:2500) for $30 \mathrm{~min}$. After incubation with primary antisera (see Table 1), sections were incubated for $30 \mathrm{~min}$ with anti-rabbit immunoglobulins 1:100 (DAKO, Code Z0421), then for 30 min with rabbit PAP (peroxidase-anti-peroxidase) 1:200 (DAKO, Glostrup, Denmark, Code Z0113), and finally were rinsed with Tris- $\mathrm{HCl}$ buffer saline (0.05 M, pH 7.4, 0.55 M NaCl). The peroxidase reaction was developed in a solution of 33 'diaminobenzidine tetrachloride $(0.04 \% \mathrm{w} / \mathrm{v}$ in Tris$\mathrm{HCl} 0.05$ M, pH 7.4) and $\mathrm{H}_{2} \mathrm{O}_{2}(0.005 \%)$. Developed sections were counterstained with Mayer's hematoxylin solution. The controls for the immunohistochemical reaction were performed by incubating other sections with normal rabbit serum (1:1000), instead of specific antiserum. These controls gave negative results. Mammalian (swine, rat) gut samples were used as positive controls. For comparative purposes, the intestinal tissues of 21 uninfected brown trout were processed similarly.

In the present survey, for comparison of the number of endocrine cells per intestinal fold among infected fish, specimens of trout with 10 to 48 Pomphorhynchus laevis per fish were chosen. This selection was based on our previous investigation (Dezfuli et al. 2002), which revealed that there was no significant difference in the number of endocrine cells of fish with $<10$ acanthocephalans and the number in fish with $>48 P$. laevis per host. Ten intestinal folds in 2 sections from 12 healthy (240 folds counted) and 11 infected (220 folds counted) trout with a range of intensity varying from 10 to $48 P$. laevis per host were observed. The mean number of enteroendocrine cells per intestinal fold that were immunoreactive to bombesin, CGRP, cholecystokinin-8 (CCK-8), $\beta$-endorphin, leu- and met-enkephalin, glucagon, NPY, SP and 5-HT antisera between uninfected (control) and parasitized groups of trout were compared with a Student's $t$-test to determine the difference of the means. The level of significance was set at a probability of 0.05 .

\section{RESULTS}

Of 124 specimens of Salmo trutta examined, 28 $(22.6 \%)$ were infected with Pomphorhynchus laevis. A total of 520 parasites were found. The intensity of infection ranged from 1 to $162(18.57 \pm 30.79$, average \pm SD) parasites per host. Acanthocephalans were found mainly in the middle and distal portions of the trout's medium intestine. 
With reference to damage caused by Pomphorhynchus laevis at the site of attachment, at least 3 main types of hosttissue reactions were noted in response to (1) the acanthocephalan moving freely in the gut lumen, (2) the parasite neck embedded in the host gut wall, and (3) the bulb and proboscis of $P$. laevis inside the gut peritoneal serosa.

In the first type of reaction, hyperplasia, congestion and leukocyte infiltration (lymphocytes and eosinophilic granular cells, EGCs) were observed in intestinal folds (Fig. 1). The apices of the folds were desquamated (Figs. 1 \& 2). The histopathological pattern was consistent with eroding, catarrhal enteritis. Near the neck penetration, the folds underwent hypoplasia and the gut epithelium contained a large number of mucus cells (Figs. 2 \& 3). With regard to the second type of damage in the propria-submucosa, away from the neck there was lymphocyte infiltration as well as the presence of numerous EGCs, whilst close to the neck fibroblastic thickening was noted (Fig. 1). In the third type of reaction, a chronic diffuse hyperplastic inflammation was observed in the peritoneal serosa.

Table 1 shows the types of antisera used, their concentrations and sources as well as their occurrence in infected and in uninfected trout. The occurrence of Pomphorhynchus laevis in the trout gut significantly increased the number of endocrine cells (Table 2) immunoreactive to CGRP, $\beta$-endorphin (Fig. 2), SP (Fig. 3), and met-enkephalin antisera (Fig. 7). Moreover, CCK-8-, bombesin- (Fig. 4), and leu-enkephalin-like (Fig. 8) immunoreactive cells were less numerous in the intestine of the parasitized in comparison to uninfected trout (Table 2). Nevertheless, in a comparison between parasitized and uninfected trout, no significant difference in the number of cells immunoreactive to antiglucagon was noted (Table 2).

A strong positive immunoreactivity was observed in the nerve fibres and neurons of the myenteric plexus of the fish infected with Pomphorhynchus laevis; the antisera involved in this positive reactivity were SP (Fig. 3), met-enkephalin (Fig. 9), VIP (Fig. 10), and bombesin (Fig. 11). Moreover, in this group of fish, higher numbers of neurons immunoreactive to anti-5-HT and anti-CGRP sera were noted in the myenteric plexus and in the inner layer of the tunica muscularis (Figs. 12 \& 13 respectively). Furthermore, in the infected fish, a higher positive immunoreactivity to bombesin antiserum was encountered in the nerve fibres of the connective axis of the
Table 2. Salmo trutta. Mean number of endocrine cells per intestinal fold (mean \pm SD) in uninfected and infected trout (240 intestinal folds were examined for uninfected, and 220 intestinal folds for parasitized fish). No endocrine cell positive to VIP was encountered

\begin{tabular}{|lccrc|}
\hline Antisera & $\begin{array}{c}\text { Uninfected } \\
\text { trout }\end{array}$ & $\begin{array}{c}\text { Infected } \\
\text { trout }\end{array}$ & $\begin{array}{c}\text { Student's } \\
t \text {-test }\end{array}$ & $\mathrm{p}$ \\
\hline Bombesin & $0.52 \pm 0.73$ & $0.20 \pm 0.49$ & 5.470 & $<0.001$ \\
CCK-8 & $2.80 \pm 2.91$ & $0.23 \pm 0.57$ & 18.187 & $<0.001$ \\
Glucagon & $2.36 \pm 2.49$ & $2.15 \pm 1.99$ & 1.729 & 0.084 \\
Leu-enkephalin & $1.86 \pm 1.74$ & $0.67 \pm 1.18$ & 8.769 & $<0.001$ \\
Met-enkephalin & $1.86 \pm 1.60$ & $3.78 \pm 2.12$ & -11.870 & $<0.001$ \\
$\beta$-endorphin & $0.31 \pm 0.57$ & $0.89 \pm 0.81$ & -10.480 & $<0.001$ \\
5-HT & $0.47 \pm 1.04$ & $0.27 \pm 0.56$ & 2.535 & $<0.05$ \\
CGRP & $0.13 \pm 0.34$ & $0.43 \pm 0.61$ & -6.585 & $<0.001$ \\
NPY & $1.54 \pm 1.34$ & $2.13 \pm 1.99$ & -4.116 & $<0.001$ \\
SP & $0.58 \pm 0.94$ & $2.37 \pm 1.77$ & -13.701 & $<0.001$ \\
\hline
\end{tabular}

host's intestinal folds (Fig. 4), although numerous cells immunoreactive to 5-HT antiserum were observed in the inflamed tissue around the neck of $P$. laevis.

In fish parasitized with Pomphorhynchus laevis, at the site of attachment some of the antisera showed a positive reaction against structures resembling nerve fibres and terminal endings in the connective tissue surrounding the bulb and the neck of the acanthocephalan. Around the praesoma of $P$. laevis, in some instances, thick and short nerve fibres reactive to SP (Fig. 14), VIP, and met-enkephalin (Fig. 15) antisera occurred. Here, the presence of a light reticular nerve fibre system reactive to bombesin (Fig. 5) and CGRP antisera was observed (Fig. 13). Furthermore, a few melanomacrophages occurred around the bulb and the neck (Fig. 13).

In infected trout, a higher number of cells immunoreactive to anti-5-HT and anti-leu-enkephalin sera were noted in the lamina propria-submucosa (Figs. $16 \& 6$, respectively).
Table 1. Primary antisera tested on sections of the medium intestine of Salmo -: low presence of structures immunoreactive . trutta infected and not infected by Pomphorhynchus laevis. ++: high presto the antiserum

\begin{tabular}{|lrllcc|}
\hline Antisera & Dilution & Source & Code & $\begin{array}{c}\text { Uninfected } \\
\text { trout }\end{array}$ & $\begin{array}{c}\text { Infected } \\
\text { trout }\end{array}$ \\
\hline Bombesin & $1: 400$ & Peninsula & IHC 7113 & + & +++ \\
CCK-8 & $1: 600$ & Peninsula & IHC 7181 & + & $+/-$ \\
Glucagon & $1: 500$ & Chemicon & AB 932 & + & + \\
Leu-enkephalin & $1: 1000$ & Genosys & CA-08-235 & $+/-$ & ++ \\
Met-enkephalin & $1: 1500$ & Peninsula & IHC 8602 & + & ++ \\
$\beta$-endorphin & $1: 1000$ & Peninsula & 8843 & $+/-$ & + \\
5-HT & $1: 1000$ & Chemicon & 61066 & $+/-$ & ++ \\
CGRP & $1: 600$ & Peninsula & IHC 6006 & $+/-$ & ++ \\
NPY & $1: 600$ & Peninsula & IHC 7180 & $+/-$ & + \\
SP & $1: 600$ & Peninsula & IHC 7451 & $+/-$ & ++ \\
VIP & $1: 600$ & Genosys & CA-08-340 & + & ++ \\
& & & & & + \\
\hline
\end{tabular}



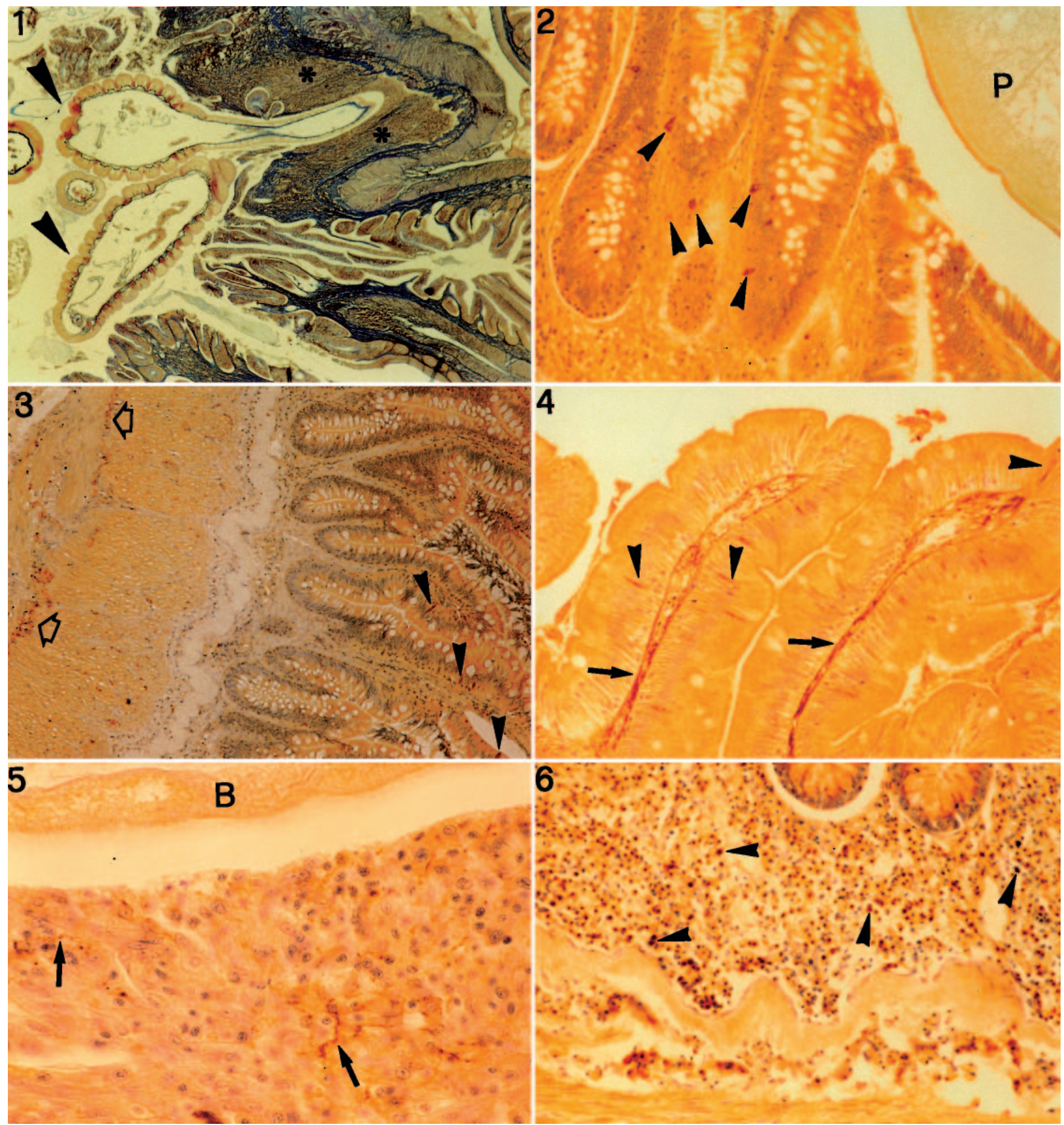

Figs. 1 to 6. Salmo trutta. Fig. 1. Micrograph showing the damage induced by attachment of 2 Pomphorhynchus laevis (arrowheads) to the intestinal wall of brown trout; fibroblastic thickening (asterisks) are visible around the neck (Azan-Mallory; $\times 26)$. Fig. 2 . Endocrine cells (arrowheads) positive to $\beta$-endorphin-like material in the epithelia of the medium intestine of brown trout infected with $\overline{P .}$ laevis $(\mathrm{P})(\times 215)$. Fig. 3. Medium intestine of parasitized fish showing endocrine cells in the epithelium cells (arrowheads) and nerve fibres (open arrows) in the myenteric plexus that are immunoreactive to the anti-Substance P serum $(\times 96)$. Fig. 4. Nerve fibres (arrows) immunoreactive to anti-bombesin serum in the connective axis of the intestinal folds of parasitized brown trout; several endocrine cells are also visible (arrowheads) $(\times 120)$. Fig. 5. Reticular system of nerve fibres (arrows) surrounding the cells which form the connective capsule around the bulb (B) of the acanthocephalan ( $\times 215)$. Fig. 6 . Large number of cells (arrowheads) containing leu-enkephalin-like material in the tunica propria-submucosa of parasitized trout $\overline{(\times 80)}$ 

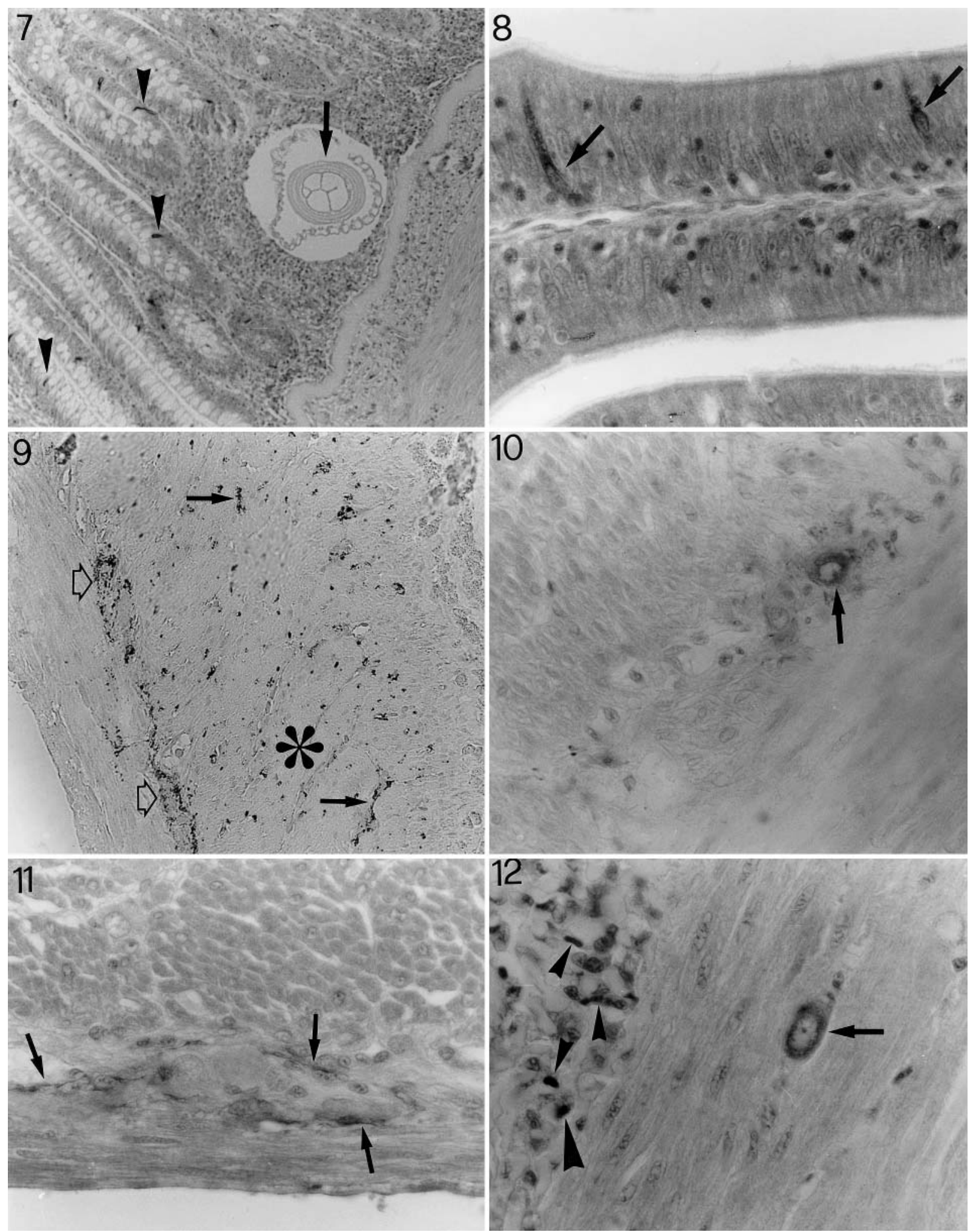

Figs. 7 to 12. Salmo trutta. Fig. 7. Endocrine cells (arrowheads) immunopositive to the antiserum against met-enkephalin in the epithelium of the medium intestine of infected brown trout; note neck of the parasite (arrow) $(\times 100)$. Fig. 8. Intestinal fold of parasitized brown trout with 2 endocrine cells (arrows) immunoreactive to the anti-leu-enkephalin serum ( $\times 560)$. Fig. 9. Immunoreactivity to the anti-met-enkephalin serum in nerve fibres (arrows) of the muscle layer (asterisk), and in the myenteric plexus (open arrows) of the gut wall of infected brown trout $(\times 160)$. Fig. 10. Neuron (arrow) immunoreactive to the anti-VIP serum in the myenteric plexus of parasitized brown trout $(\times 560)$. Fig. 11. Nerve fibres (arrows) containing bombesin-like material in the myenteric plexus of infected brown trout $(\times 550)$. Fig. $\overline{12 . ~ N e u r o n ~(a r r o w) ~ i m m u n o p o s i t i v e ~ t o ~ t h e ~ a n t i-5-H T ~ s e r u m ~ i n ~}$ the circular muscle layer of the medium intestine of parasitized brown trout; a large number of elements containing 5-HT-like material (arrowheads) are visible in the stratum granulosum $(\times 800)$ 

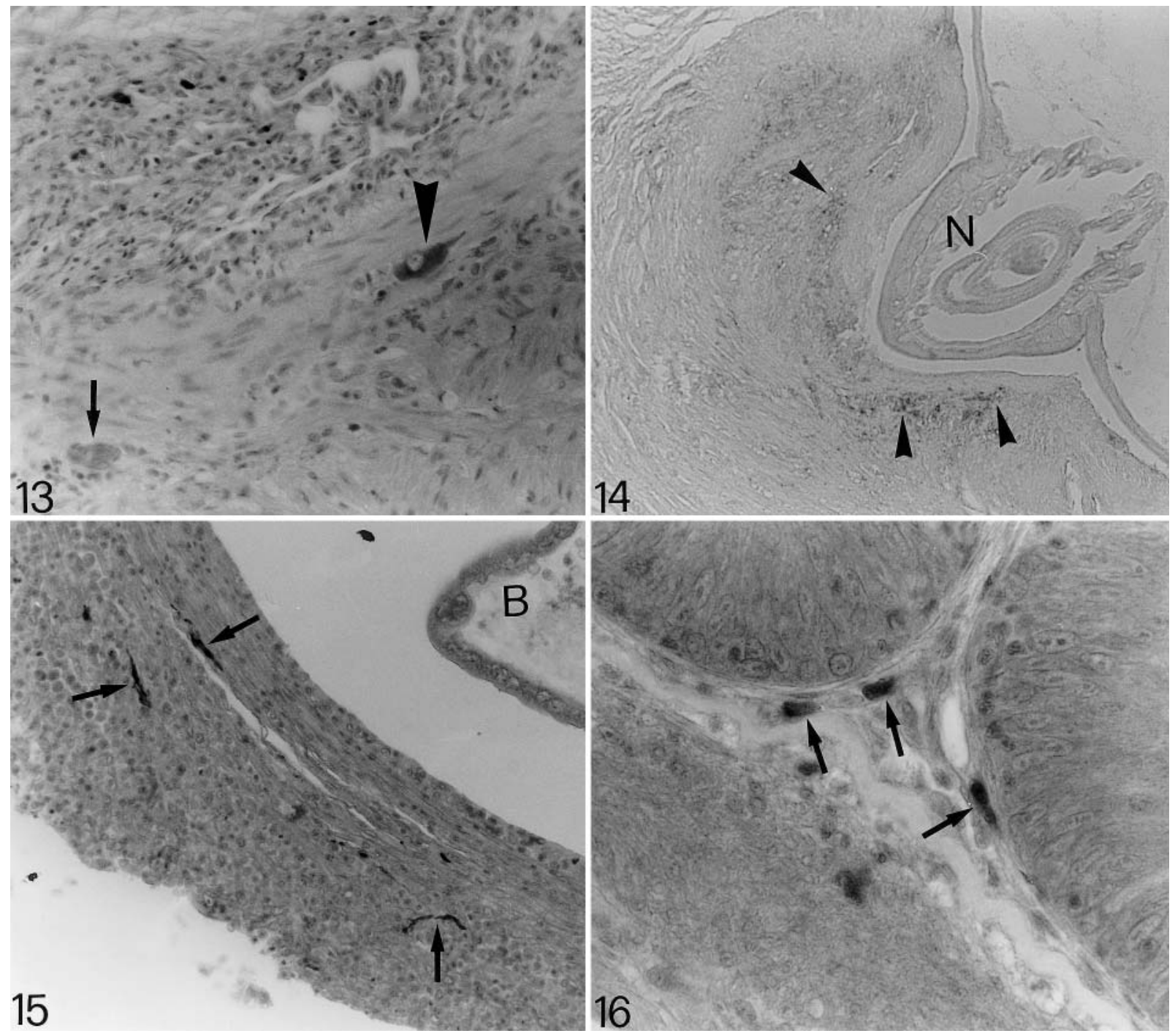

Figs. 13 to 16. Salmo trutta. Fig. 13. Neuron (arrowhead) immunoreactive to the anti-CGRP serum at the periphery of the connective capsule surrounding the bulb of Pomphorhynchus laevis; a melanomacrophage (arrow) is visible $(\times 256)$. Fig. 14. Nerve fibres (arrowheads) immunoreactive to anti-Substance P serum among the elements which constitute the capsule around the neck $(\mathrm{N})$ of $P$. laevis $(\times 100)$. Fig. 15. Nerve fibres (arrows) immunopositive to anti-met-enkephalin serum in the connective capsule surrounding the bulb $(\mathrm{B})$ of the acanthocephalan $(\times 200)$. Fig. 16. Eosinophilic granular cells (arrows) containing 5-HT-like material in the tunica propria-submucosa of infected brown trout $(\times 640)$

\section{DISCUSSION}

Hosts such as fishes tend to accumulate parasites over time (Poulin 2000). Nevertheless, there is still no agreement on the question of whether interspecific interactions play or do not play an important role in structuring the helminth communities of vertebrate digestive tracts (Poulin 2000). The brown trout Salmo trutta harbours a diverse parasite fauna within its native range (Kennedy et al. 1978). In the province of Padua, northern Italy, $S$. trutta is host to several intestinal helminth species, of which 4 are relatively common (Dezfuli et al. 2001).
Pomphorhynchus laevis was the most common parasite of brown trout in the study area. Moreover, this acanthocephalan, in various species of fishes, exhibits a distinct preference for a particular portion of the host's alimentary canal (Dezfuli 1991). As mentioned in the 'Results', $P$. laevis was found in the posterior part of the trout's middle intestine, namely behind the pyloric caeca region. The pyloric region was occupied only by Cyathocephalus truncatus, whether this cestode was the sole parasites or whether it co-occurred with $P$. laevis. The bile duct opens in this region (Halvorsen \& Macdonald 1972), and bile has been reported to stimu- 
late the movement of tapeworm larvae (Smyth 1969, p. 144-157) and is also essential for helminth growth and development (Evans \& Rycke 1969, Smyth 1969). In the present survey, the vast majority of specimens of $C$. truncatus found had the maximum dimensions recorded for the species (52 to $60 \mathrm{~mm}$ ), whereas almost all $P$. laevis individuals were small.

The enteric nervous system of vertebrates interacts with neuroendocrine cells of the intestinal mucosa (Hansen \& Skadhange 1995) as well as with inflammatory cells and fibroblasts (Pothoulakis et al. 1998) to control and regulate gut motility, transepithelial ion transport, mucosal blood flow, and immune reactions (Surprenant 1994). Peptidergic molecules and amines are involved in the communication between endocrine, nervous, and immune systems (O'Dorisio \& Panerai 1990, Fairweather 1997).

Most of the studies related to the localization, distribution, and physiology of the neuromodulators refer to mammals (Serio et al. 1998, Ebenezer 1999, Frieling et al. 1999, Kulkarni-Narla et al. 1999, Riegler et al. 1999). For this class of vertebrates, some authors reported that the occurrence of intestinal helminths induced changes in plasma (Fairweather 1997) and in the host tissue (McKay et al. 1991, Collins et al. 1997, Terenina et al. 1997). Studies have also been made of the presence and physiological features of several neuropeptides in fishes (Reinecke et al. 1997, Karila et al. 1998, Shahbazi et al. 1998, Domeneghini et al. 2000); nevertheless, in parasitized fishes this topic has received little attention. However, Maule et al. (1989) carried out a comparative study on the localisation of pancreatic polypeptide (PP) in whiting, Merlangius merlangus (Pisces: Gadidae) and its parasite Diclidophora merlangi (Monogenea: Polyopisthocotylea); the main approach of the authors was phylogenetic. Morphological changes in the neuroendocrine system of Salmo trutta due to the presence of Cyathocephalus truncatus was reported by Dezfuli et al. (2000). Within the tunica mucosa of the infected trout, an increase in the number of endocrine cells immunoreactive to SP-, met-enkephalin-, CGRP-, and 5-HT-antisera occurred (Dezfuli et al. 2000).

In trout infected with Pomphorhynchus laevis, an increase in the number of enteroendocrine cells for the neuromodulators listed above, with the exception of 5-HT, was noted, whereas a decrease in the number of endocrine elements immunoreactive to bombesin, CCK-8 and leu-enkephalin antisera was observed. With reference to glucagon, the number of endocrine cells was the same in uninfected and infected Salmo trutta.

Concerning the distribution and density of bombesin, CCK-8, and glucagon within the gut mucosa of uninfected brown trout, our data agree with those presented by Holmgren et al. (1982) and Beorlegui et al. (1992) for Oncorhynchus mykiss. Moreover, the present study showed that in infected Salmo trutta the normal distribution and density of the abovementioned neuropeptides is altered.

The occurrence of intestinal helminths is associated with higher tissue levels of 5-HT (Terenina et al. 1997), CGRP (Fairweather 1997), met-enkephalin, bombesin, and SP (McKay et al. 1991, Collins et al. 1997, Fairweather 1997). In Salmo trutta parasitized by Cyathocephalus truncatus an increase in the number of nerve fibres immunoreactive to SP, 5-HT, met-enkephalin and VIP antisera has been reported (Dezfuli et al. 2000). The same result was obtained during the present investigation on brown trout infected with Pomphorhynchus laevis.

In mammals, bombesin regulates the ion transport of the intestine (Kachur et al. 1982) and stimulates the growth of the gastrointestinal epithelium (Brown \& O'Grady 1997). This neuropeptide has an excitatory effect on isolated intestinal strip preparations of the muscle layers of rainbow trout (Holmgren \& Jönsson 1988). Similar effects have been reported in different fish species (Thorndyke et al. 1984, Jensen \& Holmgren 1985). In brown trout from the study area, several nerve fibres positive to the anti-bombesin serum were found in the myenteric plexus, in the muscle layers, and in the connective axis of the intestinal folds. These immunoreactive structures increased in infected fish, especially when Pomphorhynchus laevis was present.

In the distal ileum and colon of mice infected with Schistosoma mansoni (Trematoda), focal destruction of nerves in the myenteric plexus occurs and VIP-like immunoreactivity in the nerve fibres near granulomas increases (Varilek et al. 1991). Some neuropeptides (e.g. VIP and SP) regulate the function of immune effector cells in gut-associated lymphoid tissue (Stead 1992, Kulkarni-Narla et al. 1999). In the present study, within the connective capsule which surrounded the bulb of Pomphorhynchus laevis, nerve fibres immunoreactive to SP, CGRP, VIP, met-enkephalin, and bombesin antisera occurred. Therefore, the enteric nervous system of trout reacts against the presence of the acanthocephalan.

The potential of the framework for bi-directional communication between the neuroendocrine and the immune systems is realised through the hormonal influence of immunological peptides and the immunoregulatory functions of neuroendocrine peptides (Fairweather 1997). Several authors reported that tachykinins and other neuropeptides are involved in the immune response against some helminth infections (Thorndyke et al. 1988, Weinstock \& Blum 1989, McKay et al. 1991). In brown trout parasitized by Cyathocephalus truncatus, a high number of immune 
cells positive to SP and 5-HT antisera has been recorded (Dezfuli et al. 2000). The occurrence of Pomphorhynchus laevis induced a similar pattern.

According to Castro (1989), anatomical lesions of the digestive tract are the expression of biochemical and physiological alterations caused by intestinal parasites. Furthermore, changes in the level of one hormone could alter the function of other hormones (Fairweather 1997). On the evidence in Dezfuli et al. (2000) and in the present paper for Pomphorhynchus laevis, we hypothesise that the 2 intestinal helminths Cyathocephalus truncatus and $P$. laevis alter the physiological functioning of the host's alimentary canal.

Acknowledgements. Thanks are due to W. J. Poly from Southern Illinois University for the English revision of draft of the manuscript. This investigation was supported by grants from the Italian Ministry of University and Scientific Research and Technology.

\section{LITERATURE CITED}

Beorlegui C, Martìnez A, Sesma P (1992) Endocrine cells and nerves in the pyloric caeca and the intestine of Oncorhynchus mykiss (Teleostei): an immunocytochemical study. Gen Comp Endocrinol 86:483-495

Blalock JE (1989) A molecular basis for bidirectional communication between the immune and neuroendocrine systems. Physiol Rev 69:1-32

Brown DR, O'Grady SM (1997) Regulation of ion transport in the porcine intestinal tract by enteric neurotransmitters and hormones. Comp Biochem Physiol A 118:309-317

Bullock WL (1963) Intestinal histology of some salmonid fishes with particular reference to the histopathology of acanthocephalan infections. J Morphol 112:23-35

Bykhovskaya-Pavlovskaya I (1964) Key to parasites of freshwater fish of the U.S.S.R. Leningrad, Israel Program for Scientific Translations, Jerusalem

Castro GA (1989) Immunophysiology of enteric parasitism. Parasitol Today 5:11-19

Castro GA (1992) Intestinal physiology in the parasitized host: integration, disintegration, and reconstruction of systems. Ann NY Acad Sci 664:369-379

Collins SM, Vanassche G, Hogaboam C (1997) Alterations in enteric nerve and smooth-muscle function in inflammatory bowel diseases. Inflamm Bowel Dis 3:38-48

Dezfuli BS (1991) Histopathology in Leuciscus cephalus (Pisces: Cyprinidae) resulting from infection with Pomphorhynchus laevis (Acanthocephala). Parassitologia (Rome) 33:137-145

Dezfuli BS, Capuano S, Barbieri C, Volponi S (1998) Pathobiology associated with the acanthocephalan Southwellina hispida in the alimentary canal of Phalacrocorax carbo (Aves). In: Kane AS, Poynton SL (eds) 3rd Int Symp Aquat Animal Health, Baltimore, MD, Aug 30-Sep 3, 123. Baltimore

Dezfuli BS, Arrighi S, Domeneghini C, Bosi G (2000) Immunohistochemical detection of neuromodulators in the intestine of Salmo trutta Linnaeus naturally infected with Cyathocephalus truncatus Pallas (Cestoda). J Fish Dis 23:265-273

Dezfuli BS, Giari L, De Biaggi S, Poulin R (2001) Associations and interactions among intestinal helminths of the brown trout, Salmo trutta, in northern Italy. J Helminthol 75:1-6

Dezfuli BS, Giari L, Simoni E, Bosi G, Manera M (2002) Histopathology, immunohistochemistry and ultrastructure of the intestine of Leuciscus cephalus (L.) naturally infected with Pomphorhynchus laevis (Acanthocephala). J Fish Dis 25:7-14

Domeneghini C, Radaelli G, Arrighi S, Mascarello F, Veggetti A (2000) Neurotransmitters and putative neuromodulators in the gut of Anguilla anguilla (L.). Localizations in the enteric nervous and endocrine systems. Eur J Histochem 44:295-306

Ebenezer IS (1999) Intraperitoneal, but not subcutaneous, administration of the sulphated cholecystokinin octapeptide (CCK-8S) inhibits operant and nonoperant food intake in rats: implications for the CCK-satiety hypothesis. Methods Find Exp Clin Pharmacol 21:167-171

Evans WS, Rycke PH (1969) The in vitro cultivation of Hymenolepis. Parasitology 59: 20

Fairweather I (1997) Peptides: an emerging force in host responses to parasitism. In: Beckage NE (ed) Parasites and pathogens: effects on host hormones and behavior. Chapman \& Hall, New York, p 113-139

Foster N, Lee DL (1996) A vasoactive intestinal polypeptidelike protein excreted/secreted by Nyppostrongylus brasiliensis and its effect on contraction of uninfected rat intestine. Parasitology 112:97-104

Frieling T, Dobreva G, Weber E, Becker K, Rupprecht C, Neunlist M, Schemann M (1999) Different tachykinin receptors mediate chloride secretion in the distal colon through activation of submucosal neurons. NaunynSchmiederberg's Arch Pharmacol 359:71-79

Halvorsen O, Macdonald S (1972) Studies on the helminth fauna of Norway XXVI: the distribution of Cyathocephalus truncatus (Pallas) in the intestine of brown trout (Salmo trutta L.). Norw J Zool 20:265-272

Hansen MB, Skadhauge E (1995) New aspects of the pathophysiology and treatment of secretory diarrhoea. Physiol Res 44:61-78

Holmgren S, Jönsson AC (1988) Occurrence and effects on motility of bombesin related peptides in the gastrointestinal tract of the Atlantic cod, Gadus morhua. Comp Biochem Physiol C 89:249-256

Holmgren S, Vaillant C, Dimaline R (1982) VIP-, substance P-, gastrin/CCK-, bombesin-, somatostatin- and glucagonlike immunoreactivities in the gut of the rainbow trout, Salmo gairdneri. Cell Tissue Res 223:141-153

Jensen J, Holmgren S (1985) Neurotransmitters in the intestine of the Atlantic cod, Gadus morhua. Comp Biochem Physiol C Comp Pharmacol C 82:81-89

Kachur JF, Miller RJ, Field M, Rivier J (1982) Neurohumoral control of ileal electrolyte transport: I. Bombesin and related peptides. J Pharmacol Exp Ther 220:449-455

Karila P, Shahbazi F, Jensen J, Holmgren S (1998) Projections and actions of tachykininergic, cholinergic, and serotonergic neurones in the intestine of the atlantic cod. Cell Tissue Res 291:403-413

Kennedy CR, Broughton PF, Hine PM (1978) The status of brown and rainbow trout, Salmo trutta and $S$. gairdneri as hosts of the acanthocephalan, Pomphorhynchus laevis. J Fish Biol 13:265-275

Kulkarni-Narla A, Beitz AJ, Brown DR (1999) Catecholaminergic, cholinergic and peptidergic innervation of gutassociated lynphoid tissue in porcine jejunum and ileum. Cell Tissue Res 298:275-286

Maule AG, Shaw C, Halton DW, Johnston CF, Fairweather I (1989) Localization, quantification, and characterization of 
pancreatic polypeptide immunoreactivity in the parasitic flatworm Diclidophora merlangi and its fish host (Merlangius merlangus). Gen Comp Endocrinol 74:50-56

McDonough JM, Gleason LN (1981) Histopathology in the rainbow darter, Etheostoma caeruleum, resulting from infections with the acanthocephalans, Pomporhynchus bulbocolli and Acanthocephalus dirus. J Parasitol 67:403-409

McKay DM, Halton DW, Johnston CF, Shaw C, Fairweather I, Buchanan KD (1991) Hymenolepis diminuta: changes in the levels of certains intestinal regulatory peptides in infected C57 mice. Exp Parasitol 73:15-26

Mehlhorn H, Dubremetz JF, Franz M, Gustafsson M, Peter W, Taraschewski H, Walldorf V, Voigt WP (1988) Morphlogy. In: Mehlhorn $\mathrm{H}$ (ed) Parasitology in focus. SpringerVerlag, Heidelberg, p 161-221

O'Dorisio MS, Panerai A (1990) Neuropeptides and immunopeptides: messengers in a neuroimmune axis. Ann NY Acad Sci 594:1-503

Pothoulakis C, Castagliuolo I, Lamont T (1998) Nerves and intestinal mast cells modulate responses to enterotoxins. New Physiol Sci 13:58-63

Poulin R (2000) Variation in the interspecific relationship between fish length and intensity of parasitic infection: biological and statistical causes. J Fish Biol 56:123-137

Reinecke M, Müller C, Segner H (1997) An immunohistochemical analysis of the ontogeny, distribution and coexistence of 12 regulatory peptides and serotonin in endocrine cells and nerve fibers of the digestive tract of the turbot, Scophthalmus maximus (Teleostei). Anat Embryol 195: 87-102

Riegler M, Castagliuolo I, Wlk M, Pothoulakis C (1999) Substance P causes a chloride-dependent short-circuit current response in rabbit colonic mucosa in vitro. Scand J Gastroenterol 34:1203-1211

Serio R, Mule F, Bonvissuto F, Postorino A (1998) Tachykinins mediate noncholinergic excitatory neural responses in the

Editorial responsibility: Wolfgang Körting,

Hannover, Germany circular muscle of the rat proximal colon. Can J Physiol Pharmacol 76:684-689

Shahbazi F, Karila P, Olsson C, Holmgren S, Conlon JM, Jensen J (1998) Primary structure, distribution, and effects on motility of CGRP in the intestine of the cod Gadus morhua. Am J Physiol Reg Int Comp Physiol 44:R19-R28

Smyth JD (1969) The physiology of cestodes. Oliver \& Boyd, Edinburgh

Stead RH (1992) Innervation of mucosal immune cells in the gastrointestinal tract. Reg Immunol 4:91-99

Surprenant A (1994) Control of the gastrointestinal tract by enteric neurons. Annu Rev Physiol 56:117-140

Taraschewski H (1989) Acanthocephalus anguillae in intraand extraintestinal positions in experimentally infected juveniles of goldfish and carp and in sticklebacks. J Parasitol 75:108-118

Taraschewski H (2000) Host-parasite interactions in Acanthocephala: a morphological approach. Adv Parasitol 46: $1-179$

Terenina NB, Asatrian AM, Movsessian SO (1997) Neurochemical changes in rats infected with Trichinella spiralis and T. pseudospiralis. Dokl Biol Sci 355:412-413

Thorndyke M, Holmgren S, Nilsson S, Falkmer S (1984) Bombesin potentiation of the acetylcholine response in isolated strips of fish stomach. Regul Pept 9:350

Thorndyke MC, Riddell JH, Dimaline R, Balagun K, Whitfield PJ (1988) Changes in ileal vasoactive intestinal polypeptide and gastrin-releasing peptide/bombesin levels associated with chronic infections of the digenean helminth Echinostoma liei. Regul Pept 22:435

Varilek GW, Weinstock JV, Williams TH, Jew J (1991) Alterations of the intestinal innervation in mice infected with Schistosoma mansoni. J Parasitol 77:472-478

Weinstock JV, Blum AM (1989) Tachykinin production in granulomas of murine Schistosomiasis mansoni. J Immunol $142: 3256-3261$

Submitted: July 27, 2001; Accepted: January 3, 2002 Proofs received from author(s): July 15, 2002 